\title{
NOTES AND QUERIES.
}

Section of Laryngology of the Rotal Society of Medicine: Summer CONGRESs, 1920.

The Summer Congress of the Section will be held on Thursday and Friday, June 24 and 25. The meeting, which will be devoted to a discussion and the reading of papers, will commence on the Thursday at 2 p.m. There will also be a Museum and an Exhibition of Instruments. This meeting will take the place of the usual monthly meeting on June 4.

Members who intend to read papers are requested to send the titles not later than April 1, and summaries of their papers not later than May 1, to the Secretaries, Dr. Irwin Moore, 30A, Wimpole Street, London, W. 1, or to Mr. Charles Hope, 58, Wimpole Street, W. 1.

The British Medical Association.

The first meeting of the above Association since 1914 will take place this year at Cambridge, from June 30 till July 3, that is to say, on the week following the Summer Congress of the Laryngological Section of the Royal Society of Medicine (see above notice).

At the Association meeting there is to be no special section of Oto-Laryngology, but oto-laryngologists may attend and read papers in the surgical and other sections if they so desire.

Otological Serction of the Rotal Society of Medicine.

The next meeting of this Section will be held on March 19 . Notices and papers to be sent in not later than May 9. Secretaries : Mr. H. Buckland Jones and Mr. Lionel Colledge.

Laryngologtcal Section of the Royal Society of Medicine.

The next monthly meeting of this Section will be held on May 7. Notices and papers to be sent in not later than April 25. Secretaries : Dr. Irwin Moore and Mr. C. W. Hope.

\section{BOOK RECEIYED.}

John Coakley Lettsom, and the Foundation of the Medical Society of London. By Sir StClair. Thomson, M.D., President of the Society, Pp. 62. With 4 plates and 14 figures in the text. Price $2 s .6 d$. London: Harrison \& Sons. 
NOW READY.

Fully Illustrated in Colours and Black and White. Price 20/- net.

MEDICAL ANNUAL, 1919.

\title{
A YEAR=BOOK OF TREATMENT, AND PRACTITIONER'S INDEX:
}

\author{
Being a Review of the World's Progress in Medicine and \\ Surgery. Arranged in Alphabetical Order for Easy Consultation.
}

\section{Contributors :}

E. WYLLYS ANDREWS, A.M., M.D., Chicago. JOSEPH BLOMFIELD, B.A., M.D. FRANCIS J. CHARTERIS, M.D., B.CH. JOHN D. COMRIE, M. D., F.R.C.Y. CAREY F. COOMBS, M.D., F.R.C.H. W. H. DOLAMORE, M.K.C.s., I., D.s.k.c.s. W. E. FOTHERGILI, M.A., N.D. JOHN S. FRASER, M.R., F.R.C.S. HERBERT FRENCH, M.A., M.D. EDWARD W. GOODALI, M.D., B.s. Major E. W. heY GRoves, r.a.M.c.(T.). C. THURSTAN HOLLAND, M.R.C.S., L.R.C.F. J. RAMSAY HUNT, M.D., New York. ROBERT HUTCHISON, M.D., F.R.C.P. CECIL A. JOLL, M.., , m. FREDERICK LANGMEAD, N.D., F.R.C.P.
ARTHUR LATHAM, M.A., M.1), F.R.C.P. E. G. GRAHAM LITTJE, N.D., F.R.C.P.

C. F. MARSHALL, M.D., F.R.c.s.

R, FOSTER MOORE, M.A., F.R.C.S. CAPT. MAURICE NICOJL, R.A.M.C. HERBERT S. PENDLEBURY, M.A., F.R.C.S. BEDFORD PIERCE, M.D., F.R.C.P. JOSEPH PRIESTLEY, B.A., M.D., D.P.H. SIR LEONARD ROGERS, I.t.Col. I.M.S.; s., , F.R.c.s.

J. D. ROLLESTON, M.A., M.D.

A. RENDLE SHORT, M.D., B.S., F.R.c.S.

J. W. THOMSON WALKER, F.R.C.S.

W. I. DE COURCY WHEELLR, F.R.C.s.

P. WATSON WILLIAMS, M.D.

S. A. KINNIER WILSON, M.A., M.D, F.R.C.P. Associate Editors:

(Medicine) CAREY F, COOMBS, M.D., F.K.C.P. ; (Surgery) A. RENDLE SHORT, M.D., B.s., F.R.c.s.

THE new volume of the Medical Annual is of unusual value and interest. The experiences gained by the War have produced advances in medical science and practice which, under ordinary conditions, would have required many years to reach.

This progress will be found chronicled in the Annual, and adapted in every way possible to the requirements of the practitioner.

From Press Notices.

British .Medical Journal. - "Good reading, and an excellent investment."

Lancet. - "A valuable addition to the library of the Medical Practitioner; contains in one volume a practical summary of the progress of medicine during the past year."

Last year's volume was exhausted soon after publication, and, to avoid disappointment, early application is advised for this iseue.

Bristol: JOHN WRIGHT \& SONS LTD. London: SIMPKIN, MARSHALL \& CO. LTD. 


\section{Dr. Irwin Moore's UNIVERSAL FORCEPS}

For Removing Foreign Bodies from the Esophagus, Trachea, or Bronchi.

\section{And ENDOSCOPIC CUTTING FORCEPS or SHEARS}

And

For Cutting through Tooth-plates, Pins, or Bones.

Dr. William Hill's EXPANDING CESOPHAGOSCOPE

For assisting in Removal of Impacted Tooth-plates, etc.

See LANCET, May 13 th, 1916.
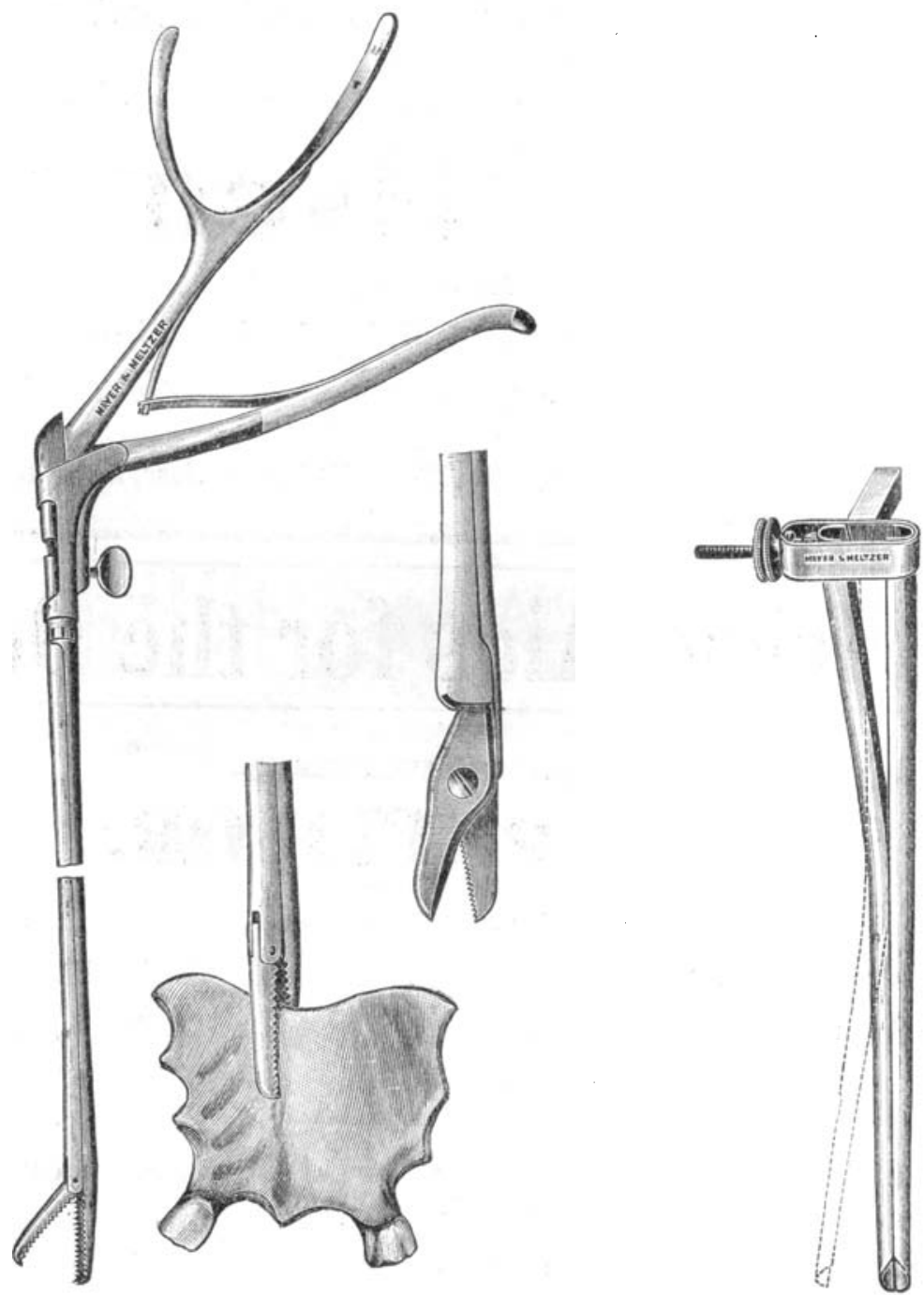

FULL PARTICULARS ON APPLICATION. 


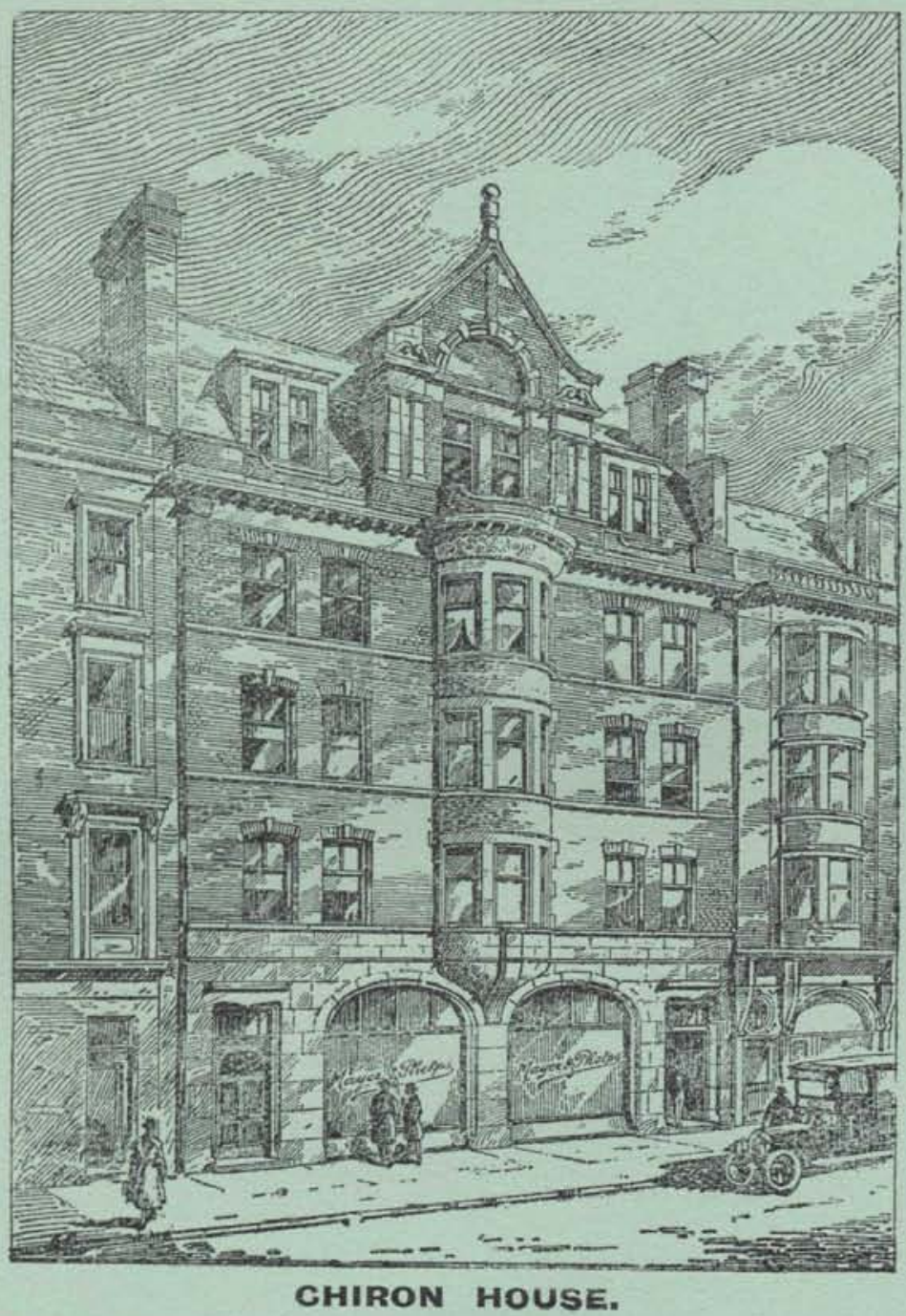

MAYER \& MELTZER have removed to the above premises where their business will be carried on in future under the name of MAYER \& PHELPS, the two Partners who have been the sole proprietors and managers for many years (Meltzer's interest ceased at his death thirty-five years ago),

Larger Showrooms are available for the display of Instruments, Aseptic Furniture, etc., and, as in the past, no effort will be spared to maintain and enhance the reputation for design and workmanship of Mayer's Surgical Tools.

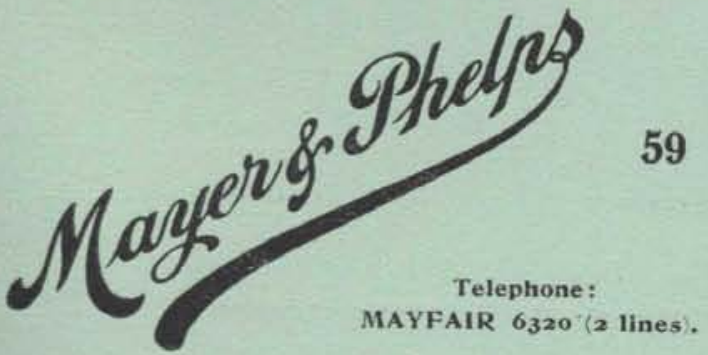

ฮ

\section{CHIRON HOUSE,}

59 and 61, New Cavendish Street, LONDON, W. 1 . 


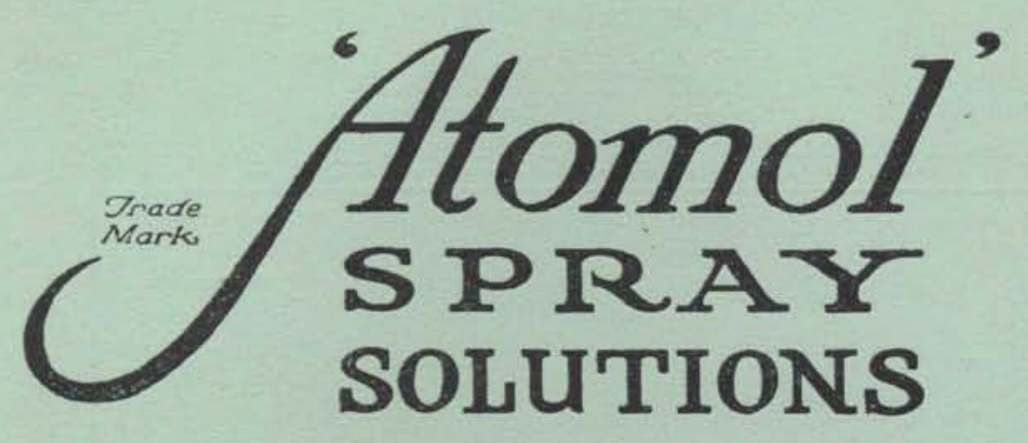

A comprehensive

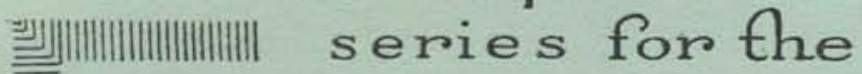

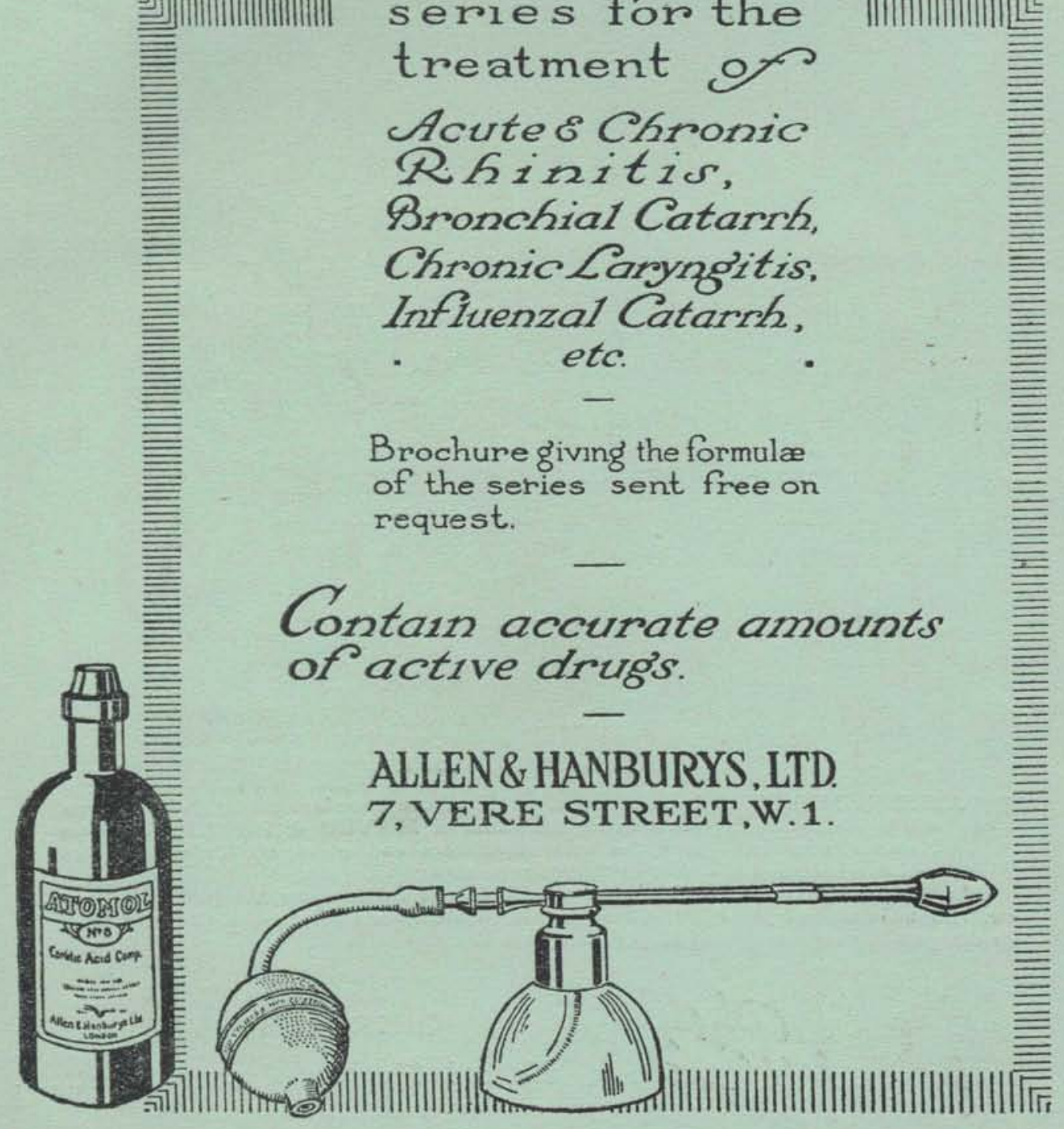

